\title{
Reduced glycogen synthase activity in skeletal muscle from obese patients with and without Type 2 (non-insulin-dependent) diabetes mellitus
}

\author{
P.Damsbo ${ }^{1}$, A. Vaag $^{2}$, O. Hother-Nielsen ${ }^{1}$ and H. Beck-Nielsen $^{2}$ \\ ${ }^{1}$ Hvidöre Hospital, Klampenborg and ${ }^{2}$ Department of Endocrinology, Odense University Hospital, Denmark
}

\begin{abstract}
Summary. In order to evaluate the importance of a defect in insulin mediated non-oxidative glucose metabolism and glycogen synthase activity in skeletal muscles in obese subjects with and without Type 2 (non-insulin-dependent) diabetes mellitus we studied: 10 lean and 10 obese control subjects and 12 obese diabetic patients using the euglycaemic hyperinsulinaemic clamp technique (basal, $20 \mathrm{mU} \cdot\left(\mathrm{m}^{2}\right)^{-1} \cdot \mathrm{min}^{-1}$, $\left.80 \mathrm{mU} \cdot\left(\mathrm{m}^{2}\right)^{-1} \cdot \mathrm{min}^{-1}\right)$ in combination with indirect calorimetry. Muscle biopsies were taken from $m$. vastus lateralis at each insulin level. We found that non-oxidative glucose metabolism could be stimulated by insulin in all three groups $(p<0.01)$. The values obtained at the highest insulin levels (around $140 \mu \mathrm{U} / \mathrm{ml}$ ) were lower in both obese groups compared to the lean control subjects $(118 \pm 21,185 \pm 31$, $\left.249 \pm 14 \mathrm{mg} \cdot\left(\mathrm{m}^{2}\right)^{-1} \cdot \mathrm{min}^{-1}(p<0.01)\right)$. Insulin stimulation of the glycogen synthase activity at a glucose-6-phosphate concentration of $0.1 \mathrm{mmol} / \mathrm{l}$ was absent in both obese groups,
\end{abstract}

while activities increased significantly in the lean control subjects $(19.6 \pm 4.2 \%$ to $45.6 \pm 6.8 \%, p<0.01)$. Glycogen synthase activities at the highest insulin concentrations only differed significantly between lean control subjects and obese diabetic patients $(45 \pm 7 \%$ and $31 \pm 5 \%, p<0.05$ ). We conclude that insulin resistance in peripheral tissues in obese subjects with and without Type 2 diabetes may be partly explained by a reduced insulin mediated non-oxidative glucose metabolism and that this abnormality might be due to an absent insulin stimulation of glycogen synthase in skeletal muscles. This enzyme defect is correlated to obesity itself.

Key words: Type 2 (non-insulin-dependent) diabetes, obesity, insulin resistance, non-oxidative glucose metabolism, skeletal muscle, glycogen synthase.
Insulin resistance in peripheral tissues of obese patients with Type 2 (non-insulin-dependent) diabetes mellitus is reflected in both reduced glucose oxidation and reduced non-oxidative glucose metabolism [1-7]. The abnormal non-oxidative glucose metabolism seems to play the quantitatively most important role $[8,9]$ and has furthermore been demonstrated in first degree relatives to Type 2 diabetic patients [10]. Therefore, this defect could be of primary origin. The key enzyme in this metabolic pathway in skeletal muscle is glycogen synthase $[11,12]$, and has been found to correlate positively to non-oxidative glucose metabolism [13]. Glycogen synthase activity is reduced in obese Type 2 diabetic patients after a meal [14], and recently the importance of this defect for the development of insulin resistance was further emphasized when it was shown that patients with low insulin-mediated glucose disposal had a lower glycogen synthase activity than lean subjects with normal glucose disposal [15]. Whether this defect in glycogen synthase activity is due to obesity itself or a characteristic feature in obese Type 2 diabetic patients remains unanswered. Another important question is whether the glycogen synthase defect is of primary origin or a secondary event due to metabolic abnormalities such as high plasma glucose and non-esterified fatty acid (NEFA) values. To eliminate this "metabolic insulin resistance", plasma glucose and NEFA values are generally normalized by acutely raised plasma insulin concentrations. The question is, however, whether this rapid increase in plasma insulin is able to reverse a metabolic insulin resistance? If not, a primary or secondary defect in glycogen synthase activities may not be revealed by this method. The purpose of our study, therefore, was to investigate:

1. whether non-oxidative glucose metabolism and glycogen synthase activity in skeletal muscle at physiological insulin concentrations was reduced in obese Caucasians with Type 2 diabetes,

2. whether these defects could be explained by obesity itself, and 
3. whether the defects could be overcome by an $8 \mathrm{~h}$ pre-investigation period with normalized plasma glucose values.

\section{Subjects and methods}

\section{Subjects}

Twelve newly diagnosed obese patients with Type 2 diabetes (OD) were studied and compared to 10 obese control subjects (OC), and 10 lean control subjects (LC). The control subjects were matched for age and sex and had normal glucose tolerance and no family history of diabetes. Clinical data are presented in Table 1.

No patient had received any kind of anti-diabetic medicine, and none suffered from liver or kidney disease as evaluated by clinical and standard laboratory examinations. None had received any medication which is known to influence the glucose or lipid metabolism. Prior to participation the purpose and risks of the study were carefully explained to all the subjects and their informed consent was obtained. The protocol was approved by the local Ethical Committee of Copenhagen and is in accordance with the Helsinki Declaration.

\section{Study protocol}

Patients were admitted to the hospital in the evening before the day of the study and connected to a glucose controlled insulin infusion system (Biostator, Life Science Instruments, Miles Lab., Elkhart, Ind., USA). A catheter was inserted into a dorsal wrist vein for continuous blood sampling and blood glucose analyses. Blood glucose was normalized before midnight through insulin infused via a catheter inserted into an antecubital vein in the contralateral arm. The glucose analyser of the biostator was calibrated hourly throughout the night using a Beckman glucose analyser (Beckman Instruments, Fullerton, Calif., USA). Blood glucose was clamped at $5.0 \pm 0.5 \mathrm{mmol} / \mathrm{l}$ throughout the night.

In the morning a bolus of $25 \mu \mathrm{Ci} 3{ }^{3} \mathrm{H}$-glucose followed by a continuous infusion $(0.25 \mu \mathrm{Ci} / \mathrm{min})$ was given in order to assess total glucose disposal $(\mathrm{Rd})[16]$.

Euglycaemic hyperinsulinaemic clamp. Insulin infusions were performed at three levels by a modification of the technique of DeFronzo [17]. After $2 \mathrm{~h}$ of tritiated glucose infusion, all subjects were studied for $30 \mathrm{~min}$ at their basal insulin levels. Euglycaemia in diabetic patients was maintained by means of an insulin infusion (Actrapid, Novo, Bagsvaerd, Denmark) which was necessary to overcome the individual insulin resistance.

Clamp 1 and $2\left(20\right.$ and $\left.80 \mathrm{mU} \cdot\left(\mathrm{m}^{2}\right)^{-1} \cdot \mathrm{min}^{-1}\right)$ were performed by continuous insulin infusion. These insulin levels were chosen in order to stay close to physiological insulin concentrations found in obese Type 2 diabetic patients. Euglycaemia was maintained by an infusion of $20 \%$ glucose by the Biostator (mode 7:0) and external infusion pumps (Infusomat). When glucose infusion from the Biostator exceeded $150 \mathrm{mg} / \mathrm{min}$ for more than $3 \mathrm{~min}$ an external glucose infusion was started or increased by $100 \mathrm{mg} / \mathrm{min}$. After $120 \mathrm{~min}$ of insulin infusion, the subjects were considered to be in a condition of steady-state and the results presented are mean values for the following period of $30 \mathrm{~min}$, with blood samples collected every $10 \mathrm{~min}$.

Glucose disposal. Total glucose disposal (Rd) was calculated from the plasma concentrations of tritiated glucose and plasma glucose using Steele's non-steady situations equation [18]. At the highest insulin level when the glucose production from the liver presumably is zero, glucose infusion rates (GIR) were used to calculate glucose disposal (Rd).

Glucose and lipid oxidation. Indirect calorimetry was performed using a computerized flowthrough canopy gas analyser system (Deltatrac Metabolic Monitor, Datex Instr. Corp., Helsinki, Finland). Briefly, air is sucked at a rate of $40 \mathrm{l} / \mathrm{min}$ through a canopy placed over the head of the subject. Samples of the inspired and expired air
Table 1. Clinical data of the groups studied

\begin{tabular}{|c|c|c|c|}
\hline & $\begin{array}{l}\text { Lean } \\
\text { control } \\
\text { subjects }\end{array}$ & $\begin{array}{l}\text { Obese } \\
\text { control } \\
\text { subjects }\end{array}$ & $\begin{array}{l}\text { Obese } \\
\text { diabetic } \\
\text { patients }\end{array}$ \\
\hline $\operatorname{Sex}(M / F)$ & $7 / 3$ & $7 / 3$ & $10 / 2$ \\
\hline Age (years) & $51(42-62)$ & $47(39-71)$ & $51(41-59)$ \\
\hline BMI $\left(\mathrm{kg} / \mathrm{m}^{2}\right)$ & $22.2 \pm 0.6$ & $31.9 \pm 2.5^{\mathrm{a}}$ & $31.0 \pm 1.2^{\mathrm{a}}$ \\
\hline $\begin{array}{l}\text { Fasting } \\
\text { Plasma glucose } \\
\quad(\mathrm{mmol} / \mathrm{l})\end{array}$ & $5.0 \pm 0.2$ & $5.4 \pm 0.1$ & $11.6 \pm 1.1^{\mathrm{b}}$ \\
\hline $\begin{array}{l}\text { Plasma insulin } \\
(\mu \mathrm{U} / \mathrm{ml})\end{array}$ & $10.0 \pm 1.7$ & $23.2 \pm 5.0^{\mathrm{a}}$ & $21.7 \pm 3.3^{\mathrm{a}}$ \\
\hline
\end{tabular}

Fasting plasma glucose and insulin values were sampled on the morning of the day before the study

a $p<0.01$ compared to lean control subjects; ${ }^{\mathrm{b}} p<0.01$ compared to lean and obese control subjects

are analysed for oxygen concentration using a paramagnetic differential oxygen sensor and for carbon dioxide using an infrared carbon dioxide sensor. Signals from the gas analysers are processed by the computer, and oxygen consumption and carbon dioxide production are calculated and recorded once a min. After an equilibration period of $10 \mathrm{~min}$ the average gas exchanges in the $30 \mathrm{~min}$ study period were used to calculate rates of glucose oxidation and lipid oxidation.

Nitrogen excretion was assessed from urine samples throughout the study period and corrected for changes in pool size [19]. Glucose, lipid and protein oxidation was calculated from Frayn's equation [20].

\section{Non-oxidative glucose disposal was calculated as:}

$\mathrm{Rd}$-oxidized glucose, and expressed in units of $\mathrm{mg} \cdot\left(\mathrm{m}^{2}\right)^{-1} \cdot \mathrm{min}^{-1}$.

Muscle biopsies. At the end of each study period (basal, clamp 1 and clamp 2) a muscle biopsy was taken from $m$. vastus lateralis $20 \mathrm{~cm}$ above the knee, under local anaesthesia (2\% lidocaine without epinephrine) using a modified Bergstrøm needle (Stille-Werner, Copenhagen, Denmark). Biopsies were immediately (within 20 s) frozen in liquid nitrogen. Before the enzyme analyses muscle biopsies were freeze-dried and microdissected free from non-muscle constituents (blood, fat and connective tissue). Thereafter, the muscle fibers were homogenized and assayed by a modification of the method of Thomas et al. [14]. Briefly, glycogen synthase activity was estimated by incubation of homogenates with ${ }^{14} \mathrm{C}$-UDPG $(0.3 \mathrm{mmol} / \mathrm{l})$ using glucose-6-phosphade (G6P) concentrations of $0.0,0.1$ and $10.0 \mathrm{mmol} / 1$. Enzyme activity was expressed as nmol of ${ }^{14} \mathrm{C}$-UDPG incorporated into glycogen per min per $\mathrm{mg}$ protein extract. Maximal enzyme activity was determined at saturating concentrations of G6P (10 mmol/l). Fractional velocity of glycogen synthase was calculated as a percentage of maximal activity.

Blood samples. A catheter was inserted into a hand vein in the contralateral arm of the arm infused with insulin and glucose, and the hand was placed in a heated box throughout the study. Blood samples were collected before the $3-{ }^{3} \mathrm{H}$-glucose infusion was started and every $30 \mathrm{~min}$, except during the study periods when sampling was made every $10 \mathrm{~min}$.

Blood samples were collected in fluoride treated tubes for determination of plasma glucose and plasma $3-{ }^{3} \mathrm{H}$-glucose activity, and in $2 \mathrm{ml}$ aprotenin-heparin tubes for determination of plasma insulin, $\mathrm{C}$ peptide, and in potassium-EDTA tubes for determination of NEFA. For determination of plasma lactate $2 \mathrm{ml}$ blood was precipitated in perchloric acid. Blood samples were immediately centrifuged at $5^{\circ} \mathrm{C}$ and plasma stored at $-70^{\circ} \mathrm{C}$ until assay. Plasma glucose was analysed by a routine glucose oxidase method. Tritiated glucose was analysed as previously described [21]. Plasma insulin [22], and Cpeptide [23] concentrations were measured with radioimmunologi- 
cal methods. Plasma NEFA and lactate were determined with a commercial kit using an automated analyser (Cobas Mira, Roche, Basel, Switzerland).

\section{Statistical analysis}

Non-parametric statistics were used: Mann-Whitney test for unpaired data and Wilcoxon test for paired data, and Spearmann test for correlation analyses. A significance level of 0.05 was chosen. All values are presented as means \pm SEM unless otherwise indicated.

\section{Results}

\section{Plasma insulin}

The values achieved during the insulin infusions are shown in Table 2. The basal insulin level in OD was determined by the insulin infusion rate necessary to keep the diabetic patients normoglycaemic. Insulin values obtained at the highest clamp level were not statistically significantly different between the three groups $(p>0.1)$.

\section{Rates of total glucose disposal and glucose oxidation}

Values during each study period are shown in Table 3 and Figure 1. Both glucose disposal and oxidative glucose metabolism increased statistically significantly $(p<0.01)$

Table 2. Plasma insulin concentrations $(\mu \mathrm{U} / \mathrm{ml})$ during euglycaemic hyperinsulinaemic clamp

\begin{tabular}{lccc}
\hline & $\begin{array}{l}\text { Lean } \\
\text { control } \\
\text { subjects }\end{array}$ & $\begin{array}{l}\text { Obese } \\
\text { control } \\
\text { subjects }\end{array}$ & $\begin{array}{l}\text { Obese } \\
\text { diabetic } \\
\text { patients }\end{array}$ \\
\hline $\begin{array}{l}\text { Basal insulin } \\
\text { Clamp 1 }\end{array}$ & $9.2 \pm 1.7$ & $22.7 \pm 5.0^{\mathrm{a}}$ & $35.8 \pm 5.2^{\mathrm{b}}$ \\
$20 \mathrm{mU} \cdot\left(\mathrm{m}^{2}\right)^{-1} \cdot \mathrm{min}^{-1}$ & $34.3 \pm 1.7$ & $45.8 \pm 5.7$ & $47.4 \pm 6.2$ \\
Clamp 2 & & \\
$80 \mathrm{mU} \cdot\left(\mathrm{m}^{2}\right)^{-1} \cdot \mathrm{min}^{-1}$ & $130.0 \pm 5.0$ & $148.5 \pm 10.9$ & $156.1 \pm 12.2$ \\
\hline$p<0.05 ;{ }^{\mathrm{b}} p<0.01$ compared to lean control subjects
\end{tabular}

Table 3. Glucose turnover $\left(\mathrm{mg} \cdot\left(\mathrm{m}^{2}\right)^{-1} \cdot \mathrm{min}^{-1}\right)$ during the last $30 \mathrm{~min}$ of: basal period, clamp 1 and clamp 2 , respectively

\begin{tabular}{|c|c|c|c|c|}
\hline & & $\begin{array}{l}\text { Lean } \\
\text { control } \\
\text { subjects }\end{array}$ & $\begin{array}{l}\text { Obese } \\
\text { control } \\
\text { subjects }\end{array}$ & $\begin{array}{l}\text { Obese } \\
\text { diabetic } \\
\text { patients }\end{array}$ \\
\hline \multirow[t]{2}{*}{$\begin{array}{l}\text { Basal } \\
\text { level }\end{array}$} & $\begin{array}{l}\text { Glucose } \\
\text { disposal }\end{array}$ & $83 \pm 7$ & $87 \pm 6$ & $87 \pm 2$ \\
\hline & $\begin{array}{l}\text { Glucose } \\
\text { oxidation }\end{array}$ & $60 \pm 6$ & $58 \pm 9$ & $60 \pm 9$ \\
\hline \multirow[t]{2}{*}{ Clamp 1} & $\begin{array}{l}\text { Glucose } \\
\text { disposal }\end{array}$ & $179 \pm 19$ & $120 \pm 11^{\mathrm{a}}$ & $94 \pm 9^{a}$ \\
\hline & $\begin{array}{l}\text { Glucose } \\
\text { oxidation }\end{array}$ & $113 \pm 8$ & $89 \pm 10$ & $66 \pm 6^{a}$ \\
\hline \multirow[t]{2}{*}{ Clamp 2} & $\begin{array}{l}\text { Glucose } \\
\text { disposal }\end{array}$ & $416 \pm 15$ & $309 \pm 35^{\text {a }}$ & $215 \pm 22^{\mathrm{a}, \mathrm{b}}$ \\
\hline & $\begin{array}{l}\text { Glucose } \\
\text { oxidation }\end{array}$ & $166 \pm 9$ & $125 \pm 8^{c}$ & $97 \pm 8^{\mathrm{a}, \mathrm{b}}$ \\
\hline
\end{tabular}
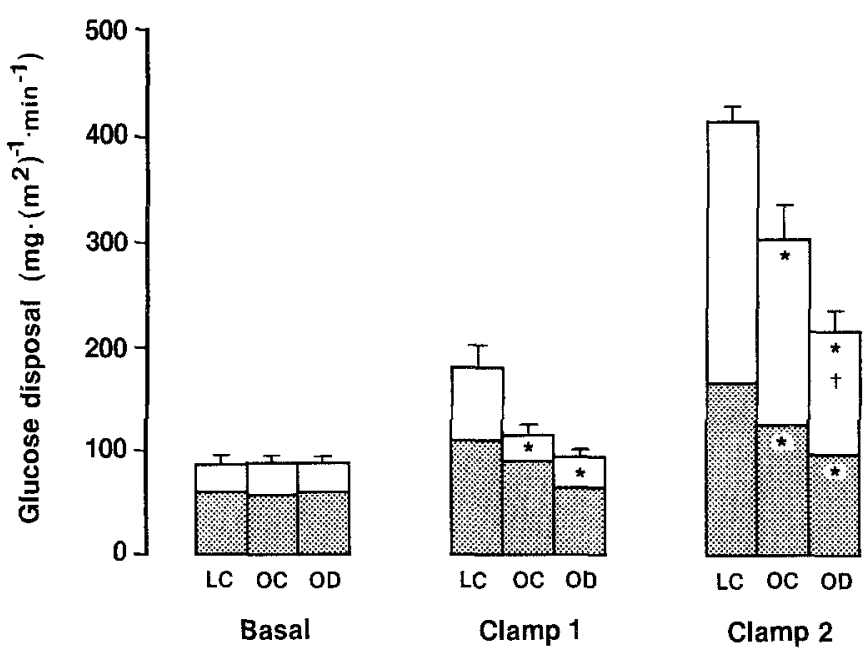

Fig. 1. Total glucose disposal rate $\left(\mathrm{mg} \cdot\left(\mathrm{m}^{2}\right)^{-1} \cdot \mathrm{min}^{-1}\right)$ during basal period, clamp 1 and clamp 2, in lean control subjects (LC), obese control subjects (OC) and obese Type 2 (non-insulin-dependent) diabetic patients (OD). $\square$ Non-oxidized glucose; oxidized glucose; ${ }^{*} p<0.01$ compared to $\mathrm{LC} ;{ }^{+} p<0.05$ OD compared to OC

from the basal state to each of the hyperinsulinaemic levels except for the first insulin level in OD $(p>0.5)$. At the highest insulin concentration both obese groups had a statistically significant lower total glucose disposal and glucose oxidation than LC $(p<0.01)$.

\section{Non-oxidative glucose metabolism}

Non-oxidative glucose metabolism was increased about ten-fold from basal to the highest insulin level in LC, whereas the increases in OC and OD were about six- and four-fold, respectively (Fig. 1). In all three groups the increase was statistically significant $(p<0.01)$. At the highest insulin level the non-oxidative glucose metabolism was significantly lower in OD compared to OC $(p<0.01)$ which again was lower than in LC $(p<0.01)$.

\section{Non-esterified fatty acids (NEFA)}

Before the study NEFA was significantly higher $(p<0.05)$ in OD $(0.86 \pm 0.05 \mathrm{mmol} / \mathrm{l})$ compared to both OC and LC $(0.67 \pm 0.09$ and $0.61 \pm 0.08 \mathrm{mmol} / \mathrm{l})$. NEFA were similar to control subjects after normalization of blood glucose during the night (Fig.2). During the clamp study insulin did not suppress NEFA to the same degree in the obese groups as in the lean control subjects (Fig. 2). At the highest insulin level NEFA concentrations were suppressed to the same level in both obese groups but were significantly higher than the lean control subjects (OD: $0.14 \pm 0.03$, OC: $0.11 \pm 0.04, \mathrm{LC}: 0.03 \pm 0.01 \mathrm{mmol} / \mathrm{l}, p<0.05)$.

\section{Lipid oxidation}

In LC lipid oxidation was suppressed with increasing insulin concentrations $\left(37 \pm 3,15 \pm 4\right.$ and $1 \pm 5 \mathrm{mg} \cdot\left(\mathrm{m}^{2}\right)^{-1}$. $\min ^{-1}, p<0.01$ ). OC showed a minor suppression which 


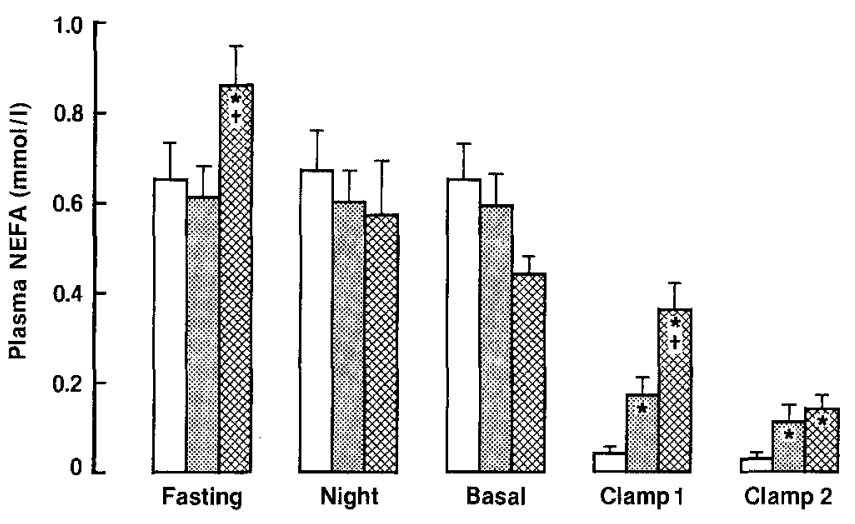

Fig. 2. Plasma NEFA (mmol/1) the day before the study (fasting), between 05.30 and 06.00 hours in the morning before the study (night), and during basal period, clamp 1 and clamp 2 level. * $p<0.01 \mathrm{com}-$ pared to lean control subjects; ${ }^{*} p<0.02$ compared to obese control subjects; $\square$ lean control subjects; obese diabetic patients
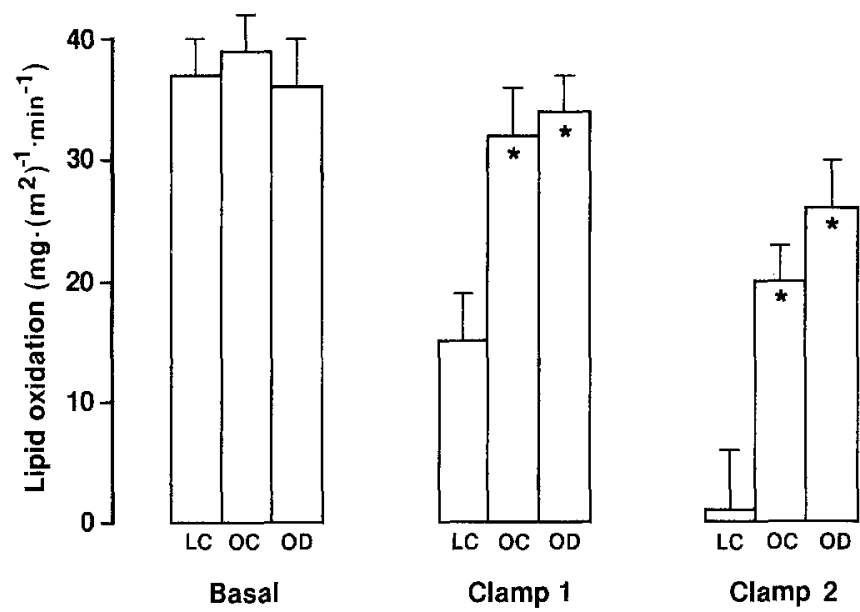

Fig.3. Lipid oxidation $\left(\mathrm{mg} \cdot\left(\mathrm{m}^{2}\right)^{-1} \cdot \mathrm{min}^{-1}\right)$ during basal period, clamp 1 and clamp 2 in lean control subjects (LC), obese control subjects (OC) and obese Type 2 (non-insulin-dependent) diabetic patients (OD). * $p<0.01$ compared to LC

was only statistically significant at high insulin concentrations $\left(39 \pm 3, \quad 32 \pm 4\right.$ and $20 \pm 3 \mathrm{mg} \cdot\left(\mathrm{m}^{2}\right)^{-1} \cdot \mathrm{min}^{-1}$, $p<0.01)$, while OD attained no statistically significant suppression $\left(36 \pm 4,34 \pm 3\right.$ and $26 \pm 4 \mathrm{mg} \cdot\left(\mathrm{m}^{2}\right)^{-1} \cdot \mathrm{min}^{-1}$, $p<0.5$ ) (Fig. 3).

\section{Glycogen synthase activity}

Maximal glycogen synthase activity (i.e. with $10 \mathrm{mmol} / 1$ G6P) did not differ statistically significantly between the groups (LC: $4.9 \pm 0.9, \mathrm{OC}: 7.4 \pm 1.2, \mathrm{OD}: 6.8 \pm 1.0 \mathrm{nmol}$. $\min ^{-1} \cdot \mathrm{mg}$ protein ${ }^{-1}, p>0.2$ ) as seen in Figure 4. The maximal glycogen synthase activities remained unchanged during insulin infusions. Insulin increased fractional velocities of glycogen synthase activity from basal to the highest insulin level, measured without G6P, in LC $(4.6 \pm 1.2 \%$ to $15.6 \pm 3.8 \%, p<0.01)$ and in $\mathrm{OC}(3.9 \pm 0.9 \%$
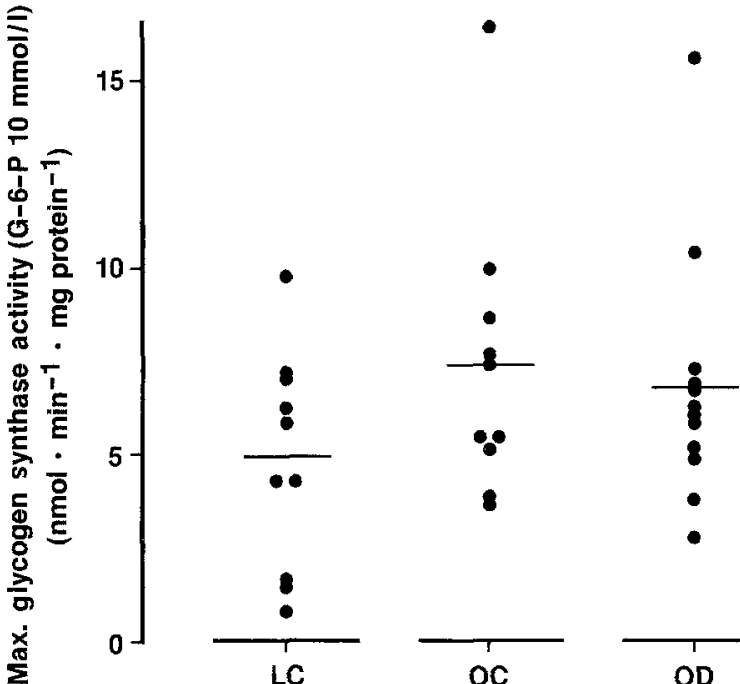

Fig.4. Individual values of maximal glycogen synthase activities $(10 \mathrm{mmol} / \mathrm{l}$ glucose-6-phosphate (G6P)) at the basal insulin level, in lean control subjects (LC), obese control subjecsts (OC), and obese diabetic patients (OD). No statistically significant difference was found between the three groups $(p>0.2)$

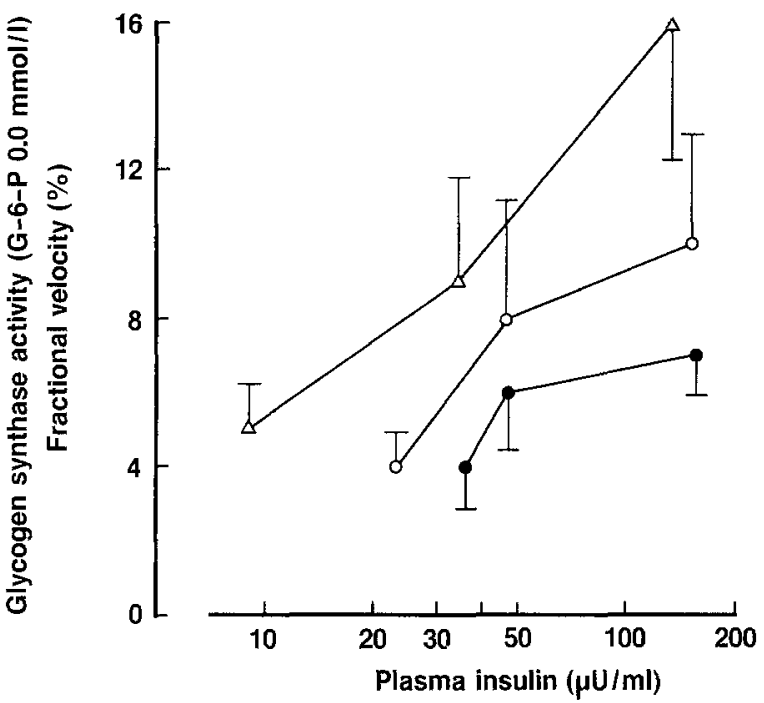

Fig.5. Glycogen synthase activity, fractional velocities (\%) when no glucose-6-phosphate (G6P) was added to the suspension. At the highest insulin level a significant difference was found between lean control subjects and obese diabetic patients $(p<0.05)$. $\triangle$ Lean control subjects; $O$ obese control subjects; $\bullet$ obese diabetic patients

to $10.1 \pm 3.1 \%, p<0.05)$, whereas no statistically significant stimulation was seen in OD $(4.1 \pm 1.2 \%$ to $6.8 \pm 1.1 \%$, $p>0.5$ ). The maximal response (glycogen synthase fractional velocity at highest insulin levels) were significantly lower in OD compared to LC $(p<0.05)$, whereas OC vs OD or OC vs LC did not differ $(p>0.1)$ as seen in Figure 5.

Studying glycogen synthase activity at physiological G6P concentrations of $0.1 \mathrm{mmol} / \mathrm{l}$ (Fig. 6), we found a similar pattern except for the OC. No statistically significant stimulation by insulin was seen in OC and OD $(p>0.1)$ but was observed in LC $(p<0.01)$. At the highest insulin values, glycogen synthase activity was significantly 


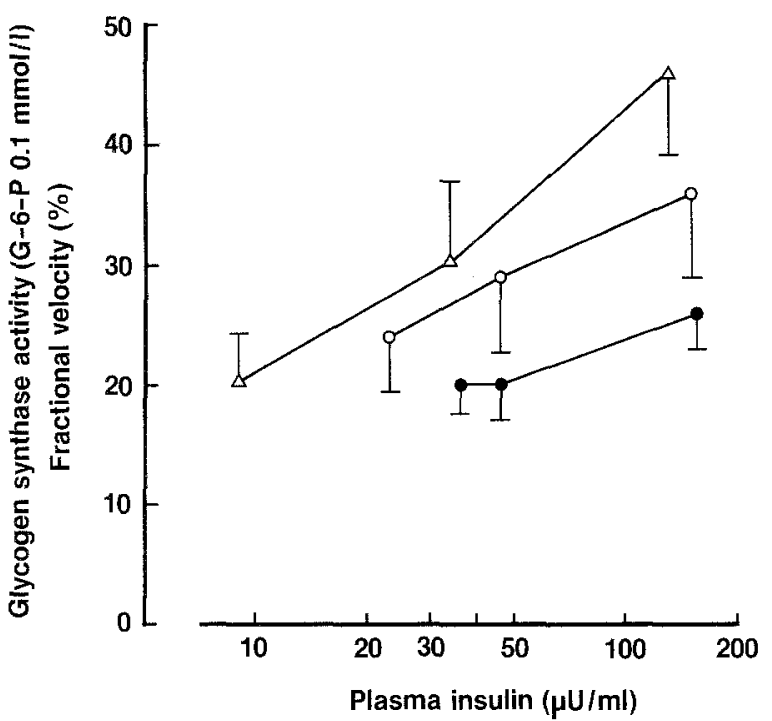

Fig.6. Glycogen synthase activity, fractional velocities (\%) at physiological glucose-6-phosphate (G6P) concentrations $(0.1 \mathrm{mmol} / \mathrm{l})$. At the highest insulin level a significant difference was found between lean control subjects and obese Type 2 (non-insulin-dependent) diabetic patients $(p<0.05)$. $\triangle$ Lean control subjects; $\bigcirc$ obese control subjects; obese diabetic patients
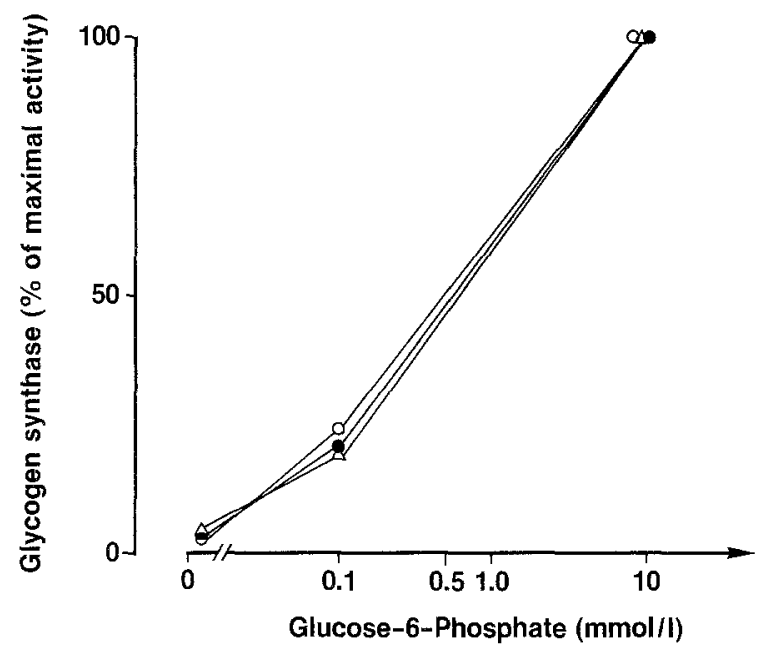

Fig. 7. Allosteric activation of glycogen synthase in the basal period, calculated as the percentage of maximal activity in all three groups. Glycogen synthase activity analysed with no glucose-6-phosphate added, $0.1 \mathrm{mmol} / \mathrm{l}$ and $10 \mathrm{mmol} / \mathrm{l}$. No difference was found between the three groups, $\mathrm{ED}_{50}=0.6 \mathrm{mmol} / \mathrm{l}(p>0.2)$. $\triangle$ Lean control subjects; $O$ obese control subjects; obese diabetic patients

lower in OD compared with LC $(p<0.05)$ with OC in between.

The allosteric activation of glycogen synthase by G6P is indicated in Figure 7 and shows that half maximal stimulation of the enzyme seems to be obtained by the same concentration of $\mathrm{G} 6 \mathrm{P}\left(\mathrm{ED}_{50}=0.60 \mathrm{mmol} / \mathrm{l}\right)$ in $\mathrm{LC}, \mathrm{OC}$ and OD $(p>0.2)$.

In order to investigate the importance of glycogen synthase activity $(0.1 \mathrm{mmol} / \mathrm{l} \mathrm{G} 6 \mathrm{P})$ in skeletal muscle for systemic non-oxidative glucose metabolism, we correlated

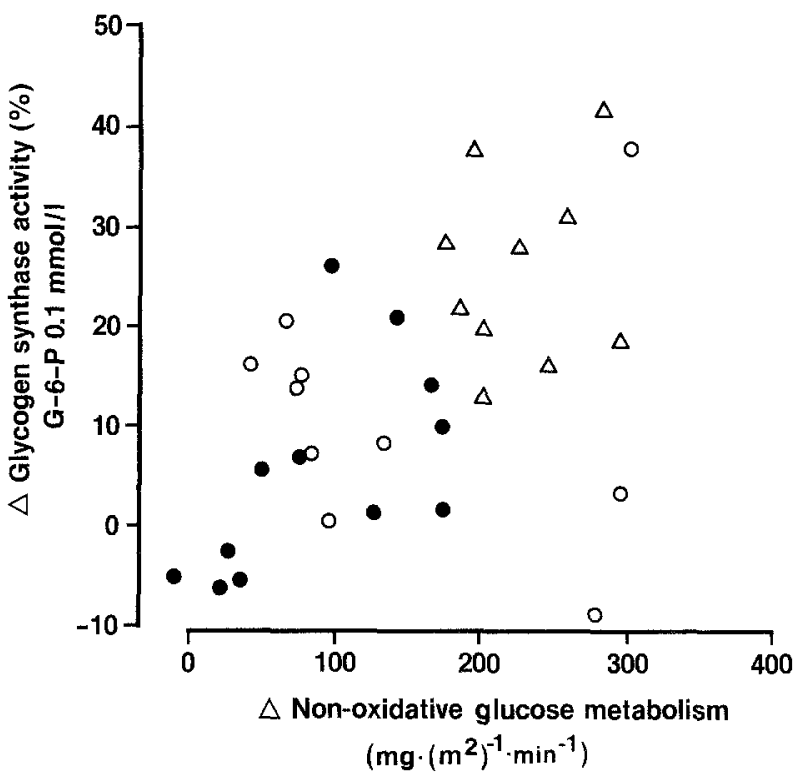

Fig. 8. The relationship between increase in glycogen synthase activity fractional velocities (glucose-6-phosphate (G6P) $0.1 \mathrm{mmol} / \mathrm{l}$ ) and increase in non-oxidative glucose metabolism during insulin infusions from basal to high insulin level. $\triangle$ Lean control subjects; $O$ obese control subjects; 0 obese diabetic patients

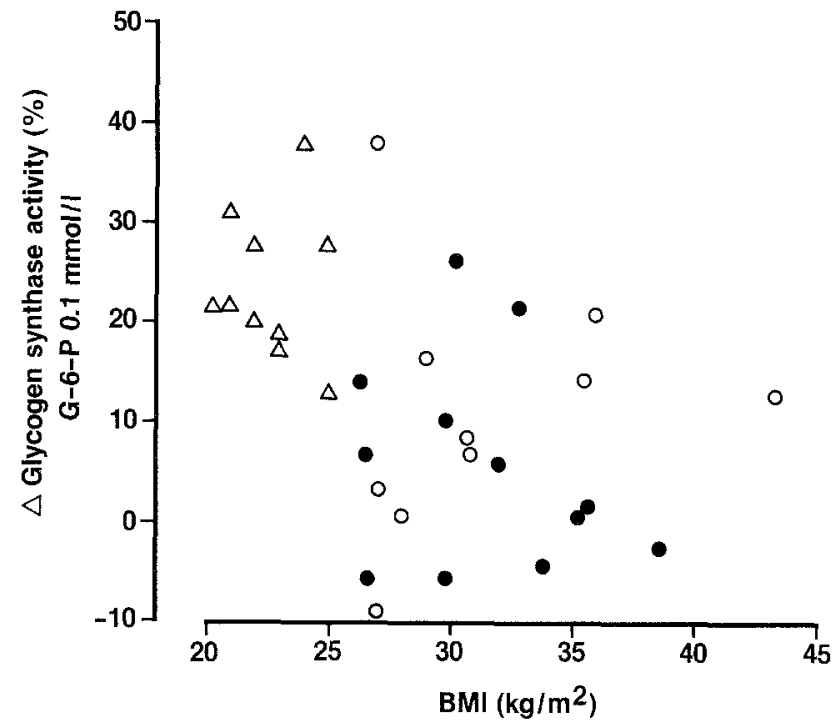

Fig. 9. The relationship between increase in glycogen synthase activity fractional velocities (glucose-6-phosphate (G6P) $0.1 \mathrm{mmol} / \mathrm{l}$ ) during insulin infusion from basal to high insulin level and obesity expressed as BMI $\left(\mathrm{kg} / \mathrm{m}^{2}\right)$. $\triangle$ Lean control subjects; $\bigcirc$ obese control subjects; obese diabetic patients

the insulin-stimulated increases of these two variables during insulin stimulation in all three groups, and found a positive correlation of $r=0.52(p<0.005)$. No statistical correlation was found in any of the subgroups (Fig.8). Since a reduced glycogen synthase activity seems to be linked to the two obese groups, we correlated the insulin mediated increase in glycogen synthase activity with BMI and found a significantly negative correlation $r=-0.52$ $(p<0.004)$ (Fig. 9). No statistically significant correlation was present in any of the subgroups. 


\section{Discussion}

Poor metabolic control in Type 2 diabetic patients resulting in hyperglycaemia and high concentrations of NEFA, are presumably factors pronouncing cellular insulin resistance (metabolic insulin resistance) [3], and reducing glucose disposal $[3,25]$. Removal of these factors opens the possibility of investigating the effect of insulin alone on intracellular glucose metabolism and the enzyme activities involved. In this study a small insulin infusion normalized plasma glucose at $5 \mathrm{mmol} / \mathrm{l}$ for $8 \mathrm{~h}$ prior to the investigation, and lowered plasma NEFA in the diabetic patients to the same level as in the control groups.

During the euglycaemic hyperinsulinaemic clamp we found that non-oxidative glucose metabolism and glucose oxidation were not stimulated to the same degree in obese subjects (OC and OD), as in lean subjects (LC), and lipid oxidation was hardly suppressed in the obese subjects. The quantitative major defect in glucose disposal was due to reduced non-oxidative glucose metabolism.

Assayed in the presence of physiological G6P values, glycogen synthase activity was not stimulated by physiological insulin concentrations in OC and OD. The dose response curves in the two obese groups seemed parallel and were shifted to the right compared to lean control groups. Glycogen synthase activity is correlated to nonoxidative glucose metabolism and BMI, and the defect in this metabolic pathway seems mainly to be linked to obesity itself.

Despite normal plasma glucose and NEFA values for $8 \mathrm{~h}$ prior to the investigation, both lipid and glucose oxidation were found to be insulin resistant during the study period. Lipid oxidation was totally suppressed in LC but only suppressed by $50 \%$ and $25 \%$ in OC and OD, respectively. The enhanced lipid oxidation in the obese subjects inhibits glycolysis and might inhibit glucose storage through negative feedback [7]. These data indicate that insulin resistance in the obese subjects was probably not secondary to metabolic derangements, but may represent a primary (not metabolic) intracellular defect. The tendency, however, to a lower non-oxidative glucose metabolism and glycogen synthase activity in OD compared to the findings in OC may be of metabolic origin. Thus, the defect in insulin stimulation of glycogen synthase activity in skeletal muscle is associated with obesity itself, but may be worsened by metabolic abnormalities as seen in OD.

The overnight induced hyperinsulinaemia (per se) in the diabetic patients, could be claimed to influence the glycogen synthase activity in this group. None the less, the insulin sensitivity of this enzyme is extremely low in Type 2 diabetic patients, and since an increase in plasma insulin of $10 \mu \mathrm{U} / \mathrm{ml}$ results in very small increases in glycogen synthase activity in LC, the hyperinsulinaemic effect in OD (from $22 \mu \mathrm{U} / \mathrm{ml}$ to $32 \mu \mathrm{U} / \mathrm{ml}$ ) is unlikely to influence the enzyme activity during the night. It is more likely, though, that muscle biopsies if taken during fasting hyperglycaemia, as in previous studies [13, 14], might increase glycogen synthase activity through an increase in the allosteric activation by G6P, and thereby partly conceal an insulin effect on the enzyme.
The sensitivity of glycogen synthase to G6P in the basal state was found to be identical in all three groups studied, leading us to the conclusion that the allosteric activation of the enzyme by G6P was normal. The finding of a more pronounced defect in glycogen synthase fractional velocity, when studied without G6P, compared to the results obtained at $0.1 \mathrm{mmol} / 1$ of $\mathrm{G} 6 \mathrm{P}$ supports this conclusion. Hyperglycaemia, in vivo, partly compensates for insulin resistance in Type 2 diabetic patients [14]. This compensation could be accomplished by an increase in allosteric activation of glycogen synthase by G6P, which is supported by the normal to increased G6P concentrations found in Pima Indians [15]. In accordance with this a defect in the glycogen synthase phosphatase has been proposed $[15,26]$ and may be the location of a primary defect.

The defect in glycogen synthase activation, however, could also be due to an insulin receptor defect, but insulin receptor number has been found to be normal in obese diabetic patients, whereas the kinase activity of the insulin receptor has been found to be abnormal [27-29]. Until now, however, no correlation between glycogen synthase and insulin receptor kinase activity has been shown.

On the basis of this it is reasonable to hypothesize that the defect in insulin-stimulated glycogen synthase activity could be due to an increased lipid oxidation in obese subjects, and furthermore a defect in glycogen synthase phosphatase in diabetic patients. Whether this defect is linked to a reduced insulin receptor kinase activity (or vice versa) has still to be studied, although the receptor kinase defect has been found to be reversible in fat cells after weight loss [30], indicating that this defect is of secondary origin.

BMI was, in our study, found to correlate negatively to the activity of glycogen synthase, indicating that obesity itself may play a role for the enzyme defect. In support of this upper body obesity has been found to be correlated to glycogen synthase activity in non-diabetic women during insulin infusion [31]. Whether reduced glycogen synthase activity is a primary defect in obese subjects leading to insulin resistance, hyperinsulinaemia and eventually to obesity is still an open question. Interestingly, insulin resistance in peripheral tissues in Pima Indians seems to be inherited [32], and first degree relatives to patients with Type 2 diabetes suffer from a reduced glucose disposal [33], and reduced non-oxidative glucose metabolism even before the oral glucose tolerance test is impaired [10].

In conclusion, we found that insulin stimulation of glycogen synthase activity was reduced in skeletal muscle from obese subjects with and without Type 2 diabetes. The defect in insulin stimulation of the enzyme could not be reversed in the diabetic patients despite $8 \mathrm{~h}$ normalization of plasma glucose and NEFA values, indicating that this defect may be of primary origin to the diabetic state. The glycogen synthase activity defect seems to be associated with obesity itself and may be of primary origin, but could also be secondary to an increased lipid oxidation in obese subjects.

Acknowledgements: This study was supported by grants from the Danish Diabetes Association. Ms. B. Mottlau and Ms. A.Forman are gratefully acknowledged for their skillfull technical assistance, Ms. K. Falholt for laboratory facilities and technical assistance. 


\section{References}

1. Kelley D, Mitrakou A, Marsh H et al. (1988) Skeletal muscle glycolysis, and storage of an oral glucose load. J Clin Invest 88: $1563-$ 1571

2. DeFronzo RA (1988) The triumvirate: beta-cell, muscle, liver. A collusion responsible for NIDDM. Diabetes 37: 667-687

3. Beck-Nielsen H, Hother-Nielsen O (1988) Insulin resistance. Diabetes Ann 4: 565-591

4. DeFronzo RA, Simonson D, Ferrannini E (1982) Hepatic and peripheral insulin resistance: a common feature of Type 2 (noninsulin-dependent) and Type 1 (insulin-dependent) diabetes mellitus. Diabetologia 23: 313-319

5. Olefsky JM (1985) Pathogenesis of insulin resistance and hyperglycemia in non-insulin-dependent diabetes mellitus. Am J Med 79 [Suppl 3B]: 1-7

6. Damsbo P, Hother-Nielsen O, Beck-Nielsen H (1988) Reduced insulin stimulated glucose oxidation in obese Type 2 (non-insulin-dependent) diabetic patients. Diabetologia 31: 483 (Abstract)

7. Felber JP, Ferrannini E, Golay A et al. (1987) Role of lipid oxidation in pathogenesis of insulin resistance of obesity and Type 2 diabetes. Diabetes 36: 1341-1350

8. Golay A, DeFronzo RA. Thorin D, Jequier E, Felber JP (1988) Glucose disposal in obese non-diabetic and diabetic Type 2 patients. A study by indirect calorimetry and euglycemic insulin clamp. Diabetes Metab 14: 443-451

9. Lillioja S, Mott DM, Zawadzki JK, Young AA, Abbot WG, Bogardus $C$ (1986) Glucose storage is a major determinant of in vivo "insulin resistance" in subjects with normal glucose tolerance. J Clin Endocrinol Metab 62: 922-927

10. Eriksson J, F-Kallunki A, Ekstrand A, Saloranta C, Widen E, Schalin C, Groop L (1989) Early metabolic defects in persons at increased risk for non-insulin-dependent diabetes mellitus. $\mathrm{N}$ Engl J Med 321: 337-343

11. Shulman D, Rothman DL, Jue T, Stein P, DeFronzo RA, Shulman RG (1990) Quantitation of muscle glycogen synthesis in normal subjects and subjects with non-insulin dependent diabetes by ${ }^{13} \mathrm{C}$ nuclear magnetic resonance spectroscopy. $\mathrm{N}$ Engl J Med 322: 223-228

12. Mandarino LJ, Wright KS, Verity LS, Nichols J, Bell JM, Kolterman OG, Beck-Nielsen H (1987) Effects of insulin infusion on human skeletal muscle pyruvate dehydrogenase, phosphofructokinase and glycogen synthase. J Clin Invest 80: 655-663

13. Bogardus C, Lillioja S, Stone K, Mott D (1984) Correlation between muscle glycogen synthase activity and in vivo insulin action in man. J Clin Invest 73: $185-190$

14. Wright KS, Beck-Nielsen H, Kolterman OG, Mandarino LJ (1988) Decreased activation of skeletal muscle glycogen synthase by mixed-meal ingestion in NIDDM. Diabetes 37:436-440

15. Kida Y, Puente AE-D, Bogardus C, Mott DM (1990) Insulin resistance is associated with reduced fasting and insulin-stimulated glycogen synthase phosphatase activity in human skeletal muscle. J Clin Invest 85: 476-481

16. Ferrannini E, Del Prato S, DeFronzo RA (1986) Glucose kinetics. Tracer methods. Methods Diabetes Res 2: 107-141

17. DeFronzo RA, Tobin JD, Andres R (1979) Glucose clamp technique, a method for quantifying insulin secretion and resistance. Am J Physiol 237: E214-223
18. Steele R (1959) Influence of glucose loading and of injected insulin on hepatic glucose production. Ann NY Acad Sci 82: 420430

19. Tappy L, Owen OE, Boden G (1988) Effect of hyperinsulinemia on urea pool size and substrate oxidation rates. Diabetes 37: $1212-1216$

20. Frayn KN (1983) Calculation of substrate oxidation rates in vivo from gaseous exchange. Am J Physiol 83: 628-634

21. Hother-Nielsen O, Schmitz O, Bak J, Beck-Nielsen H (1987) Enhanced hepatic insulin sensitivity, but peripheral insulin resistance in patients with Type 1 (insulin-dependent) diabetes. Diabetologia 30: 834-840

22. Heding LG (1966) A simplified insulin radioimmunoassay method. In: Labelled proteins in tracer studies. European Atomic Energy Community, Brussels, pp 345-350

23. Heding LG (1975) Radioimmunological determination of human C-peptide in serum. Diabetologia 11: 541-548

24. DeFronzo RA, Ferrannini E (1982) Influence of plasma glucose and insulin concentrations on plasma glucose clearance in man. Diabetes 31: 683-687

25. Randle PJ, Garland PB, Hales CN, Newsholme EA (1963) The glucose fatty-acid cycle. Its role in insulin sensitivity and the metabolic disturbances of diabetes mellitus. Lancet I: 785-789

26. Freymond D, Bogardus C, Okubo M, Stone K, Mott D (1988) Impaired insulin-stimulated muscle glycogen synthase activation in vivo in man related to low fasting glycogen synthase phosphatase activity. J Clin Invest 82: 1503-1509

27. Häring H, Obermaier B, Ermel B et al. (1987) Insulin receptor kinase defects as a possible cause of cellulat insulin resistance. Diabetes Metab 13: 284-293

28. Arner P, Pollare T, Lithell H, Livingston JN (1987) Defective insulin receptor tyrosine kinase in human skeletal muscle in obesity and Type 2 (non-insulin-dependent) diabetes mellitus. Diabetologia 30: 437-440

29. Caro JF, Sinha MK, Raju SM et al. (1987) Receptor kinase in human skeletal muscle from obese subjects with and without noninsulin dependent diabetes. J Clin Invest 79: 1330-1337

30. Freidenberg GR, Reichart D, Olefsky JM, Henry RR (1988) Reversibility of defective adipocyte insulin receptor kinase activity in non-insulin-dependent diabetes mellitus. J Clin Invest 82: 1398-1406

31. Evans DJ, Murray R, Kissebah AH (1984) Relationship between skeletal muscle insulin resistance, insulin-mediated glucose disposal, and insulin binding. J Clin Invest 74: 1515 1525

32. Bogardus C, Lillioja S, Nyomba BL et al. (1989) Distribution of in vivo insulin action in Pima Indians as mixture of three normal distributions. Diabetes 38: 1423-1432

33. Laws A, Stefanick ML, Reaven GM (1989) Insulin resistance and hypertriglyceridemia in nondiabetic relatives of patients with non-insulin-dependent diabetes mellitus. J Clin Endocrinol Metab 69:343-347

Received: 28 May 1990

and in revised form: 18 October 1990

Dr. P.Damsbo

Hvidøre Hospital

Emiliekildevej 1

DK-2930 Klampenborg

Denmark 